\title{
PENINGKATAN MANAJEMEN KINERJA TERPADU MELALUI PERENCANAAN PENINGKATAN KINERJA (PPK)
}

\author{
Oleh: \\ Endang Mulyani \\ endang_mulyani@uny.ac.id
}

\section{Abstraks}

Kinerja merupakan hasil akhir atau kemampuan kerja atas suatu pokerjaan pada waktu tertentu. Untuk meningkatkan kinerja salah satu cara yang tepat adalah melalui manajemen kinerja. Dalam proses manajemen kinerja terpadu diperlukan teknik manajemen.

Salah satu teknik manajemen yang tepat digunakan adalah melalui Perencanaan Peningkatan Kinerja PPK. Proses penyusunan PPK dilakukan melalui empat tahap. Empat tahap ini merupakan suatu rangkaian kegiatan yang saling terkait atau sebagai suatu bagan arus kegiatan.

Empat tahap tersebut yaitu: menentukan tujuan organisasi dan ukuran kinerja, mengidentifikasi dan menganalisis kekuatan-kekuatan penghambat dan pendorong kemudian menilai (memberi bobot) dampak kekuatan-kekuatan tersebut untuk menentukan kekuatankekuatan kunci, menyusun strategi dan rencana aksi, dan mengatur pelaksanaan kegiatan

\section{Pendahuluan}

Berprestasi merupakan salah satu kebutuhan bagi setiap orang (achievement needs). Setiap orang yang berkerja di dalam suatu organisasi/unit kerja selalu ingin berprestasi atau berhasil dalam berbagai bidang yang digelutinya. Sejalan dengan itu seseorang yang diterima menjadi pegawai atau diangkat menjadi pemimpin suatu organisasi/unit kerja, mereka diharapkan mampu menunjukkan kinerja yang memuas- kan, karena keberhasilan seseorang dalam melaksanakan tugas akan terlihat dari kinerja dan tingkat kontribusinya terhadap pencapaian tujuan organisasi.

Kenyataan menunjukkan bahwa tidak semua pegawai selalu giat bekerja, mampu mencapai kinerja yang diharapkan, akan tetapi dalam kenyataan sering terjadi banyak pegawai yang mengalami kesulitan dalam meningkatkan kinerjanya. Dalam kaitan itu setiap pemimpin dihadap- 
kan kepada masalah bagaimana cara meningkatkan kinerja organisasi/ unit kerja dan para pegawainya. Apabila setiap pemimpin bersama bawahannya mampu menampilkan kinerja yang memuaskan sesuai dengan bidang tugasnya masing-masing, maka kinerja atau tujuan organisasi akan tercapai, karena pemimpin dan para pegawainya menjadi pelaku organisasi merupakan kunci penentu keberhasilan mencapai tujuan organisasi.

Pengangkatan

seseorang menjadi pemimpin atau kepala pada suatu jabatan tertentu dalam organisasi, sesuai dengan konsep kepemimpinan atau manajemen merupakan pelimpahan wewenang dan tangung jawab menjalankan sebagian tugas organisasi dan memberdayakan sumber daya secara efektif dan efisien. Dalam upaya meningkatkan efektivitas pemimpin menjalankan tugas organisasi/unit kerja yang menjadi tanggung jawabnya, maka seseorang yang menjadi pemimpin dituntut untuk menguasai cara upaya meningkatkan efektivitas pemimpin menjalankan tugas organisasi/unit kerja. Salah satu cara yang dapat ditempuh seorang pemimpin dalam meningkatkan efektivitas pemimpin menjalankan tugas organisasi/unit kerjanya dapat dilakukan dengan Perencanaan $\mathrm{Pe}$ ningkatan Kinerja (PPK).

\section{Pengertian Kinerja}

Setiap pegawai yang diberikan tugas dan atau kepercayaan memimpin suatu unit organisasi/unit kerja tertentu diharapkan mampu menunjukkan kinerja yang memuaskan dan memberikan kontribusi yang maksimal terhadap pencapaian tujuan organisasi. Kinerja adalah hasil dari fungsi pekerjaan atau kegiatan tertentu selama suatu periode waktu tertentu (Bernandin \& Russel). Berdasarkan pengertian kinerja ini, ada tiga aspek yang dipahami setiap pegawai dan atau pemimpin suatu organisasi/unit kerja yakni:

1. kejelasan tugas atau pekerjaan yang menjadi tanggung jawabnya;

2. kejelasan hasil yang diharapkan dari suatu pekerjaan atau fungsi;

3. waktu yang diperlukan untuk menyelesaikan suatu pekerjaan agar hasil yang diharapkan dapat terwujud.

Berdasarkan pengertian tersebut berarti setiap pegawai harus menyadari bahwa pekerjaan yang dilakukan membuahkan suatu hasil. Jadi kinerja itu dapat diartikan sebagian hasil kerja atau kemampuan kerja yang diperlihatkan seseorang/ sekelompok orang (organisasi) atas suatu pekerjaan pada waktu tertentu. Kinerja itu dapat berupa produk akhir (barang dan jasa) dan atau berbentuk perilaku, kecakapan, kompetensi, sarana dan keterampilan spesifik 
yang dapat mondukung pencapaian lujuan, sasaran organisasi.

Setiap organisasi/unit kerja diluntut untuk mampu mengerjakan sesuatu tugas sesuai dengan fungsinya masing-masing. Mengerjakan sesuatu artinya memproses, melakukan serangkaian kegiatan yang dapat mengubah bahan (input) terIentu, menjadi keluaran (output) yang bernilai tambah dan memberikan manfaat atau dampak (outcome) bagi pengguna. Sebagian orang beranggapan bahwa hanya pekerjaan yang bersifat operasional, fisik dan bisnis yang dapat menampilkan atau menunjukkan hasil (keluaran). Sedang pekerjaan yang bersifat administratif, konsepsional atau manajemen, sulit atau tidak dapat dongan konkrit menunjukakan hasil korjanya. Anggapan demikian tidak benar, sebab semua pekerjaan yang dilakukan dengan benar pasti ada hasilnya, hanya bentuknya, ukurannya atau indikatornya yang berbeda. Hasil kerja dan ketepatan penggunaan sumber daya yang digunakan harus bisa dipertanggungjawabkan oleh setiap organisasi atau pimpinan suatu organisasi/unit kerja. Keberhasilan pelaksanaan suatu kerja dapat dilihat dari berbagai dimensi seperti dimensi waktu, dimensi kualitas dan produktivitas, seperti: ketepatan waktu menyelesaikan tugas sesuai dengan target, kualitas (kesesuaian hasil dengan standar/spesifikasi), kapasitas kerja atau produktivitas kerja atau rata-rata kemampuan kerja. Keberhasilan kerja fungsional dibidang kepegawaian dapat dilihat dari: ketepatan kualifikasi pegawai baru (dimensi kualitas), ketepatan penempatan pegawai (dimensi kualitas), ketepatan pengangkatan kedalam jabatan (Dimensi kualitas), ketepatan kenaikan pangkat (dimensi waktu), pegawai yang mengikuti diklat atau naik pangkat (dimensi produktivitas). Keberhasilan kerja di bidang manajemen strategis dapat dilihat dari: ketepatan visi dan misi, ketepatan tujuan atau sasaran, ketepatan analisis kondisi lingkungan, ketepatan waktu pelaksanaan kegiatan, program atau proyek yang disetujui. Keberhasilan di bidang tata usaha dapat dilihat dari: kecepatan pelayanan sarana kerja, kecepatan arus kerja atau informasi, kecepatan menemukan surat atau arsip, tertib pencatatan surat, surat yang selesai diproses. Keberhasilan dalam manajemen operasional dapat dilihat dari: kemampuan mencapai sasaran (seefektivitas kerja), ketepatan penggunaan sumber daya (efisiensi sumber daya), kecakapan mengoperasikan sumber daya, kemampuan mengembangkan tin kerja.

\section{Cara Meningkatkan Kinerja dan Organisasi}

Setiap orang yang menjadi anggota suatu organisasi ikut bertanggung jawab atas pencapaian kinerja organisasi sesuai bidang ker- 
ja masing-masing. Apabila setiap pegawai mampu menampilkan kinerja atas pelaksanaan kerja yang menjadi tanggung jawabnya, maka unit kerja mereka memberikan kontribusi yang baik terhadap pencapaian kinerja organisasi. Keberhasilan pegawai/karyawan mencapai kinerja dibidangnya masing-masing merupakan tanggung jawab dari atasan langsung (pimpinan). Setiap pemimpin bertanggung jawab atas kinerja bawahannya dan unit kerja atau organisasi yang dipimpinnya. Tanggung jawab pemimpin ini tercermin dalam setiap rumusan definisi pokok dalam berbagai literatur seperti dalam definisi berikut:

- kepemimpinan merupakan seni mengkoordinasikan dan memotivasi orang-orang dan kelompok untuk mencapai tujuan yang dikehendaki (John Pfittner)

- Kepemimpinan adalah proses mempengaruhi kegiatan kelompok yang terorganisir dalam upaya menuju penentuan tujuan (James $\mathrm{H}$. Donnelly. Jr)

Dalam definisi atau konsep kepemimpinan tersebut secara jelas dinyatakan bahwa pemimpin bertugas dan bertanggung jawab untuk menentukan tujuan organisasi dan berupaya mencapaianya dengan memberdayakan aggota atau pegawai maupun sumber daya lainnya. Pegawai yang ada dalam organi- sasi/unit kerja kenyataannya tidak selalu menunjukkan kinerja yang memuaskan. Oleh karena itu mereka harus dikelola dengan baik agar menjadi tenaga yang profesional. Mutasi penempatan, pengangkatan seseorang ke dalam bidang, jabatan tertentu berdasarkan profesionalisme, bertujuan untuk memperbaiki, meningkatkan kinerja mereka dan kinerja organisasi.

Setiap pemimpin pada semua level, bertanggung jawab terhadap kinerja bawahannya dan organisasi/ unit kerja yang dipimpinnya. Sejak seseorang dipilih atau diangkat memimpin suatu organisasi/unit kerja tugasnya yang pertama dan utama adalah merancang kinerja organisasi dan pegawai yang dipimpinnya. Untuk itu setiap pemimpin hendaknya memahami manajemen kinerja, sebagai suatu cara mencapai tujuan organisasi.

Cara terbaik mencapai tujuan atau meningkatkan kinerja organisasi adan karyawan adalah dengan manajemen. Hasil penelitia menunjukkan bahwa pekerjaan lebih mudah, lebih cepat selesai dan hasilnya lebih optimal kalau dikerjakan secara bersama-sama. Manajemen adalah suatu proses kerjasama sekelompok orang dalam mencapai tujuan, atau kemampuan mencapai tujuan melalui kerja sama sekelompok orang. Ada 3 fungsi utama manajemen yakni: 
- Merencanakan kinerja organisasi yang ingin dicapai.

- Menyususn rencana aksi yang akan dilaksanakan.

- Menentukan dan mengolah sumber daya yang diperlukan agar selalu tersedia cukup dan dalam kondisi siap operasional.

Ada berbagai manajemen yang diterapkan dalam mencapai kinerja (tujuan) misalnya : Managemen By Objective (MBO); Managoment By System (MBS); Management By Result (MBR); dan Management Kinerja (MK). Dalam uraian ini akan dibahas tentang manajemen kinerja. Manajemen kinerja adalah "suatu proses atau seperangkat proses untuk menciptakan pemahaman bersama mengenai apa yang harus dicapai' (bagaimana hal itu harus dicapai) serta bagaimana cara mengatur orang dengan cara yang tepat dapat meningkatkan tercapainya tujuan tersebut" (Frank Hartle). Barry Cushway mengatakan manajemen kinerja adalah "suatu proses manajemen yang dirancang untuk menghubungkan tujuan organisasi dengan tujuan individu, maupun tujuan korporasi dapat bertemu". Berdasarkan pengertian tersebut di atas bahwa aktivitas utama manajemen kinerja adalah:

- Merencanakan kinerja

Rencana kinerja yang mungkin dapat dicapai organisasi/ unit kerja yang anda pimpin. Rencana kinerja yang akan dicapai pada waktu yang akan datang merupakan perpaduan keinginan individu dan tujuan organisasi

- Pengelolaan kinerja

Setelah rencana kinerja yang ingin dicapai ditetapkan, langkah berikutnya adalah menganalisis kekuatan organisai guna mengetahui kekuatan-kekuatan yang kuat terhadap peningkatan atau pencapaian kinerja organisasi. Menilai dampak mana yang lebih diunggulkan dalam mencapai kinerja dan yang memerlukan perbaikan.

- Peninjauan kinerja

Setelah kinerja yang ingin dicapai, dan rencana aksi yang akan dilakukan termasuk orang yang diberi tanggung jawab untuk melaksanakan ditetapkan, langkah berikutnya adalah memantau pelaksanaan dan hasil kinerja yang tercapai. Memberikan umpan balik dan dukungan yang diperlukan.

- Penghargaan atas kinerja Penyampaian sikap, pendapat bernuansa motivasi, memacu perbaikan. Peningkatan kinerja sebagai salah satu bentuk penghargaan atas kinerja yang dicapai. Setiap 
pegawai bersedia melaksanakan tugas, karena mereka mengharapkan bahwa meialui imbalan yang diterimanya atas pekerjaan yang dilakukan keadaan kehidupannya akan lebih baik.

Aktivitas utama manajemen kinèrja tersebut merupakan suatu proses manajemen kinerja yang harus dilakukan secara terpadu, tidak secara parsial. Proses ini merupakan suatu siklus manajemen kinerja yang saling terkait, berkesinambungan. Hasil penelitian di Eropa menunjukkan bahwa organisasi atau manajer yang menerapkan manajemen kinerja secara konsisten kinerjanya lebih baik. Dengan menggunakan pendekatan suatu siklus manajemen kinerja, pemikiran dan rangkaian aktivitas utama yang dilakukan manajemen terarah pada perbaikan/peningkatan kinerja atau tujuan organisasi secara terus-menerus. Alasan pada manajer di Eropa menerapkan proses manajemen kinerja terpadu, karena memberikan dampak yang positif terhadap:

- Peningkatan efektivitas organisasi;

- Motivasi pegawai;

- Meningkatkan pelatihan dan pengembangan pegawai;

- Perubahan budaya kerja;

- Kaitan upah dengan produktivitas;
- Penarikan dan loyalitas ahliahli;

- Dukungan manajemen kualitas;

- Pemberian upah atas dasar perkembangan keterampilan;

- Kenaikan gaji atas kinerja.

\section{Cara Meningkatkan Kinerja Organisasi dan Karyawan Melalui PPK}

Keputusan dan tindakan yang diambil manajemen/pemimpin akan lebih signifikan kalau didukung dengan teknik analisi manajemen modern (ilmiah). Agar semakin lebih signifikan keputusan dan tindakan yang anda ambil mengenai kinerja organisasi yang akan ditingkatkan/ dicapai, sumber daya yang tepat digunakan, strategi dan rencana aksi yang tepat dilakukan, maka dalam proses manajemen kinerja, perlu didukung dengan suatu teknis analisis manajemen. Salah satu teknik yang teruji efektivitasnya adalah performance improvement planning, dalam bahasa Indonesia disebut perencanaan peningkatan kinerja (PPK).

Perencanaan adalah salah satu fungsi manajemen yang mengawali berbagai kegiatan manajemen. Perencanaan adalah sebagai berpikir ke depan mengenai jalannya kegiatan dengan mengerti betul-betul mengenai segala faktor yang tersangkut dan ditunjukkan kepada sasaran tertentu dan terukur (Charles 
J. Keating), Perencanaan adalah pemilihan sekumpulan kegiatan dan pemutusan selanjutnya apa yang harus dilakukan, kapan, dimana, bagaimana dan oloh siapa (T. Hani Handoko),

\section{Fungsi Utama Porencanaan.}

- Monentukan tujuan dan sasaran atau tujuan spesifik yang terukur yang mungkin dapat dicapai suatu organisasi/unit kerja pada waktu yang akan datang, serta alasan pertimbangannya.

- Menyusun rencana aksi yang akan dilaksanakan, meliputi:

- Rangkaian kegiatan yang terfokus ke arah pencapaian tujuan organisasi melalui suatu proses analisis situasi lingkungan organisasi (internal dan eksternal).

- Sumber daya, termasuk SDM yang tepat mendukung pelaksanaan kegiatan yang akan dilakukan

- Waktu pelaksanaan kegiatan (kapan dimulai dan selesai)

- Peninjauan rencana dan pelaksanaan kegiatan

Perencanaan berfungsi sebagai sarana pengambilan keputusan strategi menge- nai tujuan yang ingin dicapai dan penentuan rencana aksi yang dapat dilakukan dalam mencapai tujuan.

Fungsi perencaan harus mampu menyusun secara rinci mengenai:

- What : Apa yang ingin dicapai (apa hasil atau tujuan yang ingin dicapai)?

- Where : Dimana atau organisai/unit kerja mana yang dapat mencapai mewujudkan tujuan itu?

- Why : Mengapa tujuan/ hasil itu yang prioritas dicapai?

- How : Bagaimana cara mencapainya atau apa rencana strategi dan rencana yang akan dilakukan agar tujuan tercapai?

- Who : Siapa (kualifikasi apa) yang tepat untuk melaksanakan kegiatan itu dan sumber daya apa yang dibutuhkan?

- When : Kapan waktu pelaksanaan (kapan dimulai, kapan selesai, kapan ditinjau atau dipantau, dievaluasi, diberi umpan balik dan laporan pelaksanaan dengan hasilnya disampaikan atau laporan pertanggung jawabannya diberikan)? 
Perencanaan Peningkatan Kinerja (PPK) adalah suatu teknik manajemen untuk peningkatan kinerja yang mengutamakan daya analisis atas kekuatan-kekuatan pendorong dan penghambat kinerja guna menentukan strategi serta langkahlangkah kegiatan terkoordinasi dalam rangka mencapai tujuan organisasi.

Dalam pengertian PPK ini tercermin juga unsur-unsur kegiatan seperti dalam perencanaan yaitu:

- Merencanakan kinerja atau tujuan yang dicapai.

- Menentukan rencana (kekuatan yang akan diunggulkan dan yang disempurnakan melalui analisis kekuatan penghambat dan pendorong.

- Menyusun strategi dan langkah kegiatan terkoordinasi.

- Mengatur pelaksanannya.

Kalau dicermati aktivitas yang dilakukan dalam menyusun PPK sama dengan aktivitas yang tercermin dalam definisi perencanaan, dan sejalan juga dengan aktivitas dalam proses manajemen kinerja terpadu atau siklus manajemen seperti dijelaskan di depan. Pada dasarnya PPK ini merupakan suatu teknik atau pendekatan perbaikan peningkatan kinerja secara terus menerus atau berkesinambungan. Dengan cara ini diharapkan akan terus meningkat kinerja dan tingkat kontribusi dari setiap unit kerja dan pegawai terhadap pencapaian keseluruhan tujuan organisasi. Efektifitas PPK ini apabila dirujuk dengan manajemen kinerja terpadu, terletak pada komitment proses pelaksanaannya secara konsisten. Oleh karena itu persyaratan utama penyusunan PPK adalah proses proses pembahasannya dilakukan secara bersama-sama dengan bawahan. Persyaratan utama ini merupakan implementasi manajemen partisipatif. Dengan persyaratan utama ini berarti setiap pemimpin sejak awal kegiatan manajemen mendapat dukungan dan komitmen bawahan terhadap pelaksanaannya. Persyaratan pokok dalam penyusunan PPK adalah:

- Adanya kejelasan tugas pokok dan fungsi yang dirumuskan dalam setiap organisasi sehingga semua yang terlibat dalam proses kerja dapat memahaminya.

- Adanya kejelasan perumusan tujuan yang spesifik dan terukur yang akan dicapai setiap organisasi atau unit kerja dalam waktu tertentu.

- Adanya kejelasan mengenai pekerjaan yang akan dilakukan, wewenang dan tanggung jawab atas semua pekerjaan, waktu dimulai dan berakhir suatu pekerjaan, cara mengerjakan, siapa yang diberi tanggung jawab mengerjakan dan kepada 
slapa pertanggungjawaban diberikan.

- Adanya indikator kinerja untuk mengukur keberhasilan pencapaian tujuan.

- Adanya kesadaran berkomunikasi secara torbuka antar pemimpin denganstaf dan mitra kerja.

- Adanya data dan informasi yang akurat dalam penyusunan rencara kerja peningkatan kerja.

Tahap-tahap

Penyusunan

Perencanaan Peningkatan Kinerja (PPK)

Proses penyusunan PPK dilakukan melalui empat tahap. Empat tahap ini merupakan suatu rangkaian kegiatan yang saling terkait atau sebagai suatu bagan arus kegiatan. Empat tahap tersebut yaitu:

1.Menentukan tujuan organisasi dan ukuran kinerja.

Tujuan organisasi menyangkut tujuan jangka panjang, jangka pendek serta indikator kinerja (performance indicators). Tahap yang pertama ini meliputi empat lang-kah yaitu:

- Tulislah tugas pokok dan fungsi unit organisasi.

- Rumuskan tujuan jangka panjang.
- Rumuskan tujuan jangka pendek dan prioritasnya serta indikator kinerja-nya.

- Rumuskan tungkat kinerja sekarang dan tingkat kinerja yang diinginkan;

2. Mengidentifikasi dan menganalisis kekuatan-kekuatan penghambat dan pendorong kemudian menilai(memberi bobot) dampak kekuatan-kekuatan tersebut, untuk menentukan kekuatan-kekuatan kunci. Tahap yang kedua ini meliputi delapan langkah yaitu:

- Identifikasi kekuatan penghambat utama

- Tentukan dampak relatif dan mudahnya meme-cahkan kekuatan peng-hambat

- Identifikasi kekuatan pendorong utama

- Tentukan dampak relatif dan tingkat kendali keku-atan pendorong yang di-bawah pengawasan atau kontrol

- Perkiraan tingkat kekuat-an relatif pendorong dan penghambat

- Gambar diagram medan kekuatan

- Teliti keterkaitan antar kekuatan

- Pilih kekuatan kunci.

3. Menyusun strategi dan ren-cana aksi meliputi sembilan langkah yaitu: 
- Ciptakan ide strategi melalui kegiatan seimbang saran

- Kembangkan rencana kegiatan yang terkoordinasi

- Mengatur pelaksanaan kegiatan. Tahap PPK tersebut dapat dipetakan dalam suatu bagan arus sebagai berikut:

- Tahap yang ketiga ini meliputi dua langkah yaitu:

- Pilihlah tim kerja dan rumuskan peranannya

- Perkirakanlah kesulitan-kesulitan dalam pelaksanaan dan pilih strategi untuk menanggulanginya

- Musyawarahkan hal-hal utama dengan pihak ter-kait

- Prioritaskan program-program kegiatan

- Jadwalkan peninjauan kembali untuk perbaikan

\section{Penutup}

Kinerja merupakan hasil akhir atau kemampuan kerja atau sekelompok orang atas suatu pekerjaan pada waktu tertentu.Bentuk kinerja dapat berupa hasil akhir atau produk barang dan jasa, bentuk perilaku, kecakapan kompetensi, sarana, ketrampilan spesifik yang berkontribusi terhadap pencapaian tujuan organisasi.Untuk meningkatkan kinerja salah satu cara yang tepat adalah melalui manajemen kinerja. Manajemen kinerja adalah proses pemahaman tentang apa yang harus dicapai dengan menyatukan tujuan organisasi dengan tujuan individu, dan bagaimana cara mengatur aktifitas dan sumber daya yang tepat agar tujuan atau kinerja yang diinginkan dapat tercapai. Ada empat aktifitas utama manajemen kinerja yang harus dilakukan secara terpadu yakni perencanaan kinerja, pengelolaan kinerja, peninjauan kinerja, dan penghargaan atas kinerja. Dalam proses manajemen kinerja terpadu diperlukan teknik manajeme. Salah satu teknik yang tepat digunakan adalah PPK.

PPK sebagai salah satu tekik manajemen peningkatan kinerja mengutamakan analisis kekuatan pendorong dan penghambat, guna menentukan kekuatan kunci yang tepat digunakan, dan diperbaiki dan penentuan strategi serta kegiatan terkoordinasi yang akan dilakukan. Dalam proses manajemen kinerja terpadu diperlukan teknik manajemen. Salah satu teknik manajemen yang tepat digunakan adalah PPK. Proses penyusunan PPK dilakukan melalui empat tahap dan 20 langkah. Empat tahap ini merupakan suatu rangkaian kegiatan yang saling terkait atau sebagai suatu bagan arus kegiatan. Empat tahap tersebut yaitu: menentukan tujuan organisasi dan ukuran kinerja, mengidentifikasi dan menganalisis kekuatan-kekuatan penghambat dan pendorong kemudian menilai (memberi bobot) dampak kekuatan-kekuatan tersebut, 
untuk menentukan kekuatan-kekuatan kuncl, menyusun strategi dan rencena aksi, dan mengatur pelaksanaan kegiatan.

\section{Daftar Pustaka}

Agus Dharma 1991, Manajemen

Prestasi kerja Jakarta:

Rajawall Pers.

Alain Metrani. 1991, Manajemen

Sumber Daya manusia

Berdasarkan Kompetensi.

Jakarta: PT PT Intermasa.

Faustino Cardoso Gomes.1995.

Manajemen Sumber daya

manusia. Yogyakarta: Andi Off

Suryadi Prawirosentono. 1999.

Kebijakan Kinerja Karyawan.

Yogyakaaarta: BPFE
J.P.G. Sianipar. 2000. Perencanaan Peningkatan Kinerja. Kakaaaarta: Lembaga Administrasi Negara.

\section{Biodata Penulis}

Endang Mulyani, M.Si adalah dosen tetap pada Program Studi Pendidikan Ekonomi Koperasi, Fakultas IImu Sosial, Universitas Negeri Yogyakarta 